\title{
Study of factors influencing knowledge transfer in family firms
}

\author{
Ascensión Barroso Martínez, Ramón Sanguino Galván, Tomás Bañegil Palacios \\ University of Extremadura (Spain) \\ abarrosom@unex.es, sanguino@unex.es, tbanegil@unex.es
}

\section{Abstract}

Purpose: We propose in this paper to analyze what are the factors that influence knowledge transfer both intra and intergenerational in family firms. The main objective is to establish a framework that can be used later in empirical research, although we maintain a completely theoretical approach in this paper

Design/methodology/approach: This study, which is a comprehensive framework characterized the knowledge transfer literature in family firms in terms of the factors influencing them, was developed by an extensive literature review.

Findings: Based on an extensive literature review, we conclude that knowledge is best transferred when family members value the following factors: trust between family members, commitment to the family business, intergenerational relationships, intragenerational relationships, psychological ownership of the family business, successor's aspects and training, predecessor involvement in the successor training, organizational culture and relationships with Family Business Associations.

Research limitations/implications: The study demonstrates the extensiveness and variety of knowledge transfer research. However there is not the same situation in family firms' field. For academics, these different factors can be used as a map for future empirical studies.

Originality/value: There is a notable lack of research into knowledge practices in 
small and medium-sized enterprises and especially in family firms. Besides, there is a gap in the understanding of an effective way to transfer these resources across generations; actually, existing studies on knowledge management in family businesses are scarce. The main value of our paper is to fill out partially this gap.

Keywords: Knowledge management, Family firms, Knowledge transfer, Theoretical framework, Factors influencing

Jel Codes: M10, M13, M15

\section{Introduction}

The importance of the family firm in the economy of a country is an indisputable fact, even more if the consequences of their business activities in the integral development of a society are analyzed (Donckels \& Fröhlich, 1991; Basco, 2010). Studies in different countries have shown that family businesses play a key role in terms of economic growth and employment generation (Pistrui, Huang, Oksoy, Jing \& Welsch, 2001; Anderson \& Reeb, 2003). It is estimated that these kinds of companies account for 85 percent of all companies worldwide, 65 percent of the GDP and employment in Europe, and 50 percent of US GDP and 60 percent of its employment.

What actually constitutes a family business remains an open question despite decades of study and investigation (Astrachan, Klein \& Smyrnios, 2002). The majority of authors identify the following as key features of family businesses, namely, that the family participates in the ownership and management of the company; that there is an interdependence of ownership and control; and that the business is passed down through the generations with a drive for continuity (Ruiz, Sessarego \& Guzmán-Sanza, 2010).

Despite its importance, there is no a widespread opinion about what are the parameters that define its concept. Some researchers maintain that whether or not a company is in fact a family firm is determined by the distribution of ownership; Lansberg, Perrow and Rogolsky (1988, page 2) define a family business as a company in which the members of a family have the legal control over ownership. Others maintain that it depends upon who actually controls the business; Neubauer and Lank (2003, page 37) define it as that company, whether individual or corporation of any kind, in which voting control is held by a given family. For others the determining factor is the continued ownership of a company by members of a family; Fahed-Sreih and Djoundourian (2006, page 227) maintain that a family firm is any company that is controlled or influenced by a single family with the intention of staying in it. For still others, it is the combination of some or all of the above characteristics. For example, 
Davis (1983, page 47) combines ownership and management, defining it as an organisation in which the policy and management are under the significant influence of one or more nuclear families. This influence is exercised through ownership and sometimes through the involvement of family members in management. Chua, Chrisman and Sharma (1999, page 25) combine ownership, management and a drive for continuity, defining the family business as a business that is governed and / or managed with the intention of shaping and implementing the vision of the company held by a dominant coalition controlled by members of the same family, or a small number of families in a way that is potentially sustainable through generations of the family or families.

Although there are many definitions of family business, we will adopt the following definition: a family business is one in which property and / or direction of the company are held by a family that has desire of continuity, since it wants the company to continue in the future in the hands of their descendants (Barroso, Sanguino \& Bañegil, 2012).

Research concerning the family firm has increased significantly in recent years. Scholarly works that study the problems inherent in family businesses are numerous (Chrisman, Kellermanns, Chan \& Liano, 2010), mainly trying to explain the high death rate of family businesses (Lansberg \& Astrachan, 1994). One of the reasons of the failure of family businesses from the second generation may be due to the lack of ability or willingness of the family involved in the succession process of creating, sharing and transferring knowledge from one generation to another (Chirico, 2008).

Researches in the area of knowledge-based view suggest the importance of transferring through generations the tacit knowledge, networking and social capital, passion and entrepreneurship and how these transfers mean competitive advantages for family firms (Navarro de Granadillo, 2008; González-Loureiro \& Figueroa, 2012). In fact, the ability to manage knowledge is currently regarded as the greatest strength in achieving competitiveness (Añez \& Nava, 2009). However, the overwhelming majority of publications that have been influential in establishing knowledge management as an important field refer to the practices of large companies. In contrast, there is a notable lack of research into knowledge practices of small and medium-sized enterprises (Hutchinson \& Quintas, 2008; Albizu, Olazaran, Lavía \& Otero, 2011). Besides, existing studies on knowledge management in family businesses are scarce (Mazzola, Marchisio \& Astrachan, 2008; Giovannoni, Maraghini \& Riccaboni, 2011; Trevinyo-Rodríguez \& Tàpies, 2010); actually, there is a gap in the understanding to transfer of an effective way these resources across generations.

Knowledge sharing is gaining increasing recognition by researchers because of its potential benefits both to individuals and organizations, and it is fundamental to the success of a 
company (Suppiah \& Sandhu, 2011). However, most researches on knowledge are conducted at the organizational level, leaving a land fallow for the investigation of knowledge transmission at the individual level (Endres, Endres, Chowdhury \& Alam, 2007). For this reason, in this study we focus on family members' knowledge transfer, both from one generation to another, and from the same generation.

For this, we propose analyze what are the factors influence or affect knowledge transfer both intra and intergenerational in family firms. Although we will maintain a completely theoretical approach in this paper, the main objective is to establish a framework that can be used later in empirical research.

The paper is organized as follows. First we describe the theories of resource-based view and knowledge-based view, where we define knowledge in family business context. Then we explain knowledge management, focusing in the knowledge transfer activity, especially we study the factors influencing knowledge transfer. Finally, we show some conclusions.

\section{Knowledge-based view in family firms}

Before knowledge-based view (KBV), resource-based view (RBV) maintains that are the firm resources and capabilities what can explain its sustainable competitive advantages in the long term (Barney, 1991). Organizations need resources to carry out activities and produce goods and services (Suppiah \& Sandhu, 2011). This approach includes a set of inputs that have the common feature or point of departure the heterogeneity of resources between organizations and their imperfect mobility, which helps its survival to explain the sustained differences in the observed profitability (Barney, 2001; Ray, Barney \& Muhanna, 2004).

However, the mere listing of resources owned by the company does not explain its potential, i.e. this heterogeneity of resources is a necessary but not sufficient condition to a sustainable advantage. It is needed to know how the company is able to combine and exploit these resources through the organization, which will determine their capabilities (Grant, 1991; Sirmon \& Hitt, 2003; Ray et al., 2004; Sirmon, Hitt \& Ireland, 2007). The RBV can help to identify the resources and capabilities that make family firms unique and allow them to develop competitive advantages based on the family (Chrisman, Chua, \& Sharma, 2003; Sirmon \& Hitt, 2003).

Within the resources and capabilities, the resources that allow us to obtain greater competitive advantages are the intangibles, and within them the knowledge (Grant, 1996; Conner \& Prahalad, 1996), especially the existing knowledge in the organization (Priem \& Butler, 2001). Knowledge is recognized as the unique and exclusive distinctive resource and as the key and 
crucial differentiator to any organization to maintain its competitive advantage (Suppiah \& Sandhu, 2011).

In the current economic scenario, in which companies are moving towards globalization, large mergers or strategic alliances, lies a deep change in business models. In this environment, knowledge society, economies of developed countries have suffered a series of structural changes that have modified what is strategic for organizations (Zárraga Oberty \& Bonache Pérez, 2005). Face of property assets, which were the traditional basis of competitive advantages, knowledge assets have become an important resource (Zhang, Zheng, Li, Nie, Huo \& Shi, 2008) that is difficult to imitate and transferring. Knowledge is now a day the source that enables organizations to obtain better outcomes than the competence (Miller \& Shamsie, 1996). The global economy moves toward a new model based on knowledge, which is above all other tangible economic factors. Therefore, Ireland and Hitt (1999, page 44) believe that "the ability to build, share and exploit knowledge will replace property and/or control of the assets as a main source of competitive advantage."

The degree in which knowledge is integrated in a specific context determines its dependence, which has been used to transfer knowledge more effectively. Therefore, a relevant and familiar context helps in knowledge transfer (Endres et al., 2007).

Knowledge in family business is defined as the wisdom and skill that family members have acquired and developed through education and experience both inside and outside the company (Chirico, 2008). It is, therefore, a capability that should be spread across all family members in order to experiment and develop new systems of knowledge capture and collection, and experience gained by its members (Comeche Martínez, 2007). For CabreraSuárez, Saá-Pérez and García-Almeida (2001) the knowledge concept in the family business includes contextual information, framed experience, beliefs, values and expert insight, as well as the know-how and skills to perform tasks.

The family firm competitive advantage is mainly based on the tacit knowledge embedded in its resources, and especially is based on the predecessor's experience and ability. Predecessor represents the main source of skills and capabilities in the organization, who can make to lose amount knowledge to the company when he retires. Thus, founder's tacit knowledge is a strategic asset that must be transferred and developed (Bracci, 2008).

Tagiuri and Davis (1996) argue that emotional involvement, the life in common and the use of a private language in family businesses allow a communication more easily between family members. Moreover, such communication will allow them to develop idiosyncratic knowledge and specific dynamic capabilities to a resource recombination that remain (or continue) in the 
family and the company through the generations (Chirico \& Salvato, 2008; Salvato \& Melin, 2008). Undoubtedly, family businesses also have to face challenges for the creation of dynamics capabilities that support business performance.

Therefore, with the evolution of the RBV emerged the KBV, where knowledge is the companies' key or strategic asset. This approach provides the theoretical support of this work, both from a content perspective, to analyze the specific knowledge possessed by family firms, and from the analysis of the characteristics that allow family businesses maintain their competitive advantages over time.

\section{Knowledge management in family firms}

Because of the current market is more and more competitive and moves faster, knowledge management is based on that the knowledge is the only sustainable competitive advantage source for an organization: its employees' knowledge and organizations' self-knowledge (Marcu \& Watters, 2003).

There are several methodologies that may arise under the name of Knowledge Management because of the different approaches and schools that currently exist, which generate multiple and different definitions. Therefore, knowledge management is the function that plans, coordinates and controls the knowledge flows produced in the company in connection with their activities and their environment (Bueno, 1999a), in order to create essential competencies, largely explained by the resource and capability theory (Habbershon \& Williams, 1999; Barney, 2001). These knowledge flows are critical resources on which depends the company competitiveness. The results of the efficient management of these resources constitute the company intellectual capital or personal, organizational and technological competence set and relations with their environment (Bueno, 1999b; Bañegil \& Sanguino, 2006, 2007).

Liu (2010) notes that knowledge and culture are strongly linked together in organizations. There is evidence supporting the importance of culture in the success or failure of knowledge management. Proof of this, it is the case of family businesses.

Knowledge management in family businesses should emphasize the important role of the founder, learning and succession (Cabrera \& Martín, 2010). The founder is considered as the person capable of transmitting the culture that led him to set up the company and continue the business, being the main source of knowledge in the family business (Bracci, 2008). In this way, if the founder is for a long time linked to the company, he will enable the knowledge transmission, causing learning by children, who, from an early age, work in the family firm and listen to the family to talk about it (Moores, 2009; Trevinyo-Rodríguez \& Tàpies, 2010). Then, 
when the succession process is organized and produced, knowledge will be transferred from generation to generation, configuring the company's culture (Chirico \& Nordqvist, 2010).

As the company evolves, a large part of the founder's tacit knowledge is transmitted to all members of the organization, converting individual knowledge into organizational, and sometimes into explicit knowledge. In this sense, the most important aspect of knowledge management is the knowledge transfer, allowing long-term company survival.

\section{Knowledge transfer in family businesses}

The growing importance acquired of knowledge suggests the need to think about how organizations process their knowledge bases, that is, how organizations create and develop new knowledge, and how they share and transmit it (Hendriks, 1999; Wong \& Aspinwall, 2004). Furthermore, knowledge can only be developed with the communication and adds value through the use, i.e., knowledge is useful when is shared and only has value if it is exchanged (Zhang et al., 2008; Zahra, Neubaum \& Larrañeta, 2007). Thus, knowledge transfer provides the basis for the organizations' competitive advantage (Kumar \& Ganesh, 2009; Wong \& Aspinwall, 2004; Argote \& Ingram, 2000). Argote, Ingram, Levine and Moreland (2000) indicate that organizations that are able to transfer knowledge effectively from one unit to another, are more productive and more likely to survive than organizations that are less effective to knowledge transfer. Thus, it is crucial to ensure performance and sustainable growth (Brachos, Kostopoulos, Soderquist \& Prastacos, 2007; Zack, McKeen \& Singh, 2009; Chirico, Sirmon, Sciascia \& Mazzola, 2011).

Knowledge transfer refers to the knowledge communication process from one agent to another (Zapata, Rialp \& Rialp, 2009). Kumar and Ganesh (2009, page 163) define knowledge transfer as "a process of exchange of explicit or tacit knowledge between two agents, during which one agent purposefully receives and uses the knowledge provided by another." In the case of family businesses, it is the communication process from one generation to another (from parent to child) or between the same generation. Thus, to Hendriks (1999), it involves a relationship between at least two parts, one that has the knowledge (normally parents) and the other that acquires the knowledge (normally children).

Trevinyo-Rodríguez and Tàpies (2010) argue how knowledge transfer within the same firm across generation is an issue that may explain why most family business do not survive to the third generation, with a much higher mortality rate during the owner-second generation transition. Knowledge transfer is essential for organizations to help promote good practice (Lu, Leung \& Koch, 2006). In organizations, members can learn from each other and benefit from new knowledge developed by others. Transferring knowledge provides opportunities for mutual 
learning and cooperation inter and intragenerational, which in turn stimulates the creation of new knowledge (Marouf, 2007). Knowledge transfer facilitates the creation, sharing and exchange of knowledge (Gu \& Gu, 2011).

Therefore, especially in family firms, knowledge need to be accumulated by family members to generate value over time, particularly when the new generation has to assume control of the business. The knowledge transfer from a previous generation to the following is very important to manage the business efficiently, in turn this new generation has to add new knowledge and offer new perspectives to the family business. Just as it is necessary to share knowledge between different generations it is also necessary to share it between members of the same generation (Chirico, 2008). As Patel and Fiet (2011, page 1191) point, family firm members "are more committed to combining what they know with others in their firm in order to enhance their firm's competitive capabilities, etc. They are more commitment because they stand to benefit more than other over the long term". For these reason, Le Breton-Miller, Miller and Steier (2004) argue that the transfer of knowledge should start at the dining table, build up during summer jobs at the company, and continue though a career at the family firm. That transfer is facilitated when there is a close relationship between family members.

Apart from that, family businesses have certain characteristics that can produce both strengths and weaknesses for the firm (Tagiuri \& Davis, 1996; Fuentes, Fernández-Ortiz \& Cano-Rubio, 2011). Despite the fact that sharing knowledge is important, Zahra et al. (2007) point some characteristics that limit this exchange. Specifically, the most valuable knowledge in a family business is usually possessed by a single family member or a limited number of members that increases the consolidation of power and control. In this way, a limited exchange of experiences can smother the family businesses capacity to development an entrepreneurial orientation. Moreover, jealousy, which often appears when someone desires to have someone else's position, may cause a barrier to communication, deteriorating relations between family members and thereby causing a lower knowledge transfer (Stanley, Stephenson \& Monteith, 1995).

Fortunately, family businesses also possess specific characteristics that facilitate the exchange of knowledge. These characteristics are based on the family businesses' resources and capacities. Amongst these we can mention their commitment, confidence, trust, reputation, know-how, and strong sense of identity (Cabrera-Suárez et al., 2001; Sirmon \& Hitt, 2003; Bracci, 2008; Zahra et al., 2007). Moreover, these firms have a common family language that allows them to communicate more efficiently and exchange more information in greater privacy (Hoffman, Hoelscher \& Sorenson, 2006). Family businesses may represent a strong social community, defined as a network of relationships among organization members that 
leads to open communication. In this community, personal contacts are the basis for the exchange of knowledge (Zahra et al., 2007).

There are many researchers that point the lack of studies on knowledge transfer in family firms (for example: Chrisman et al., 2003; Watson \& Hewett, 2006; Mazzola, Marchisio \& Astrachan, 2008; Giovannoni et al., 2011). In response to their call for more research on this issue, we propose a set of attributes that may influence knowledge transfer:

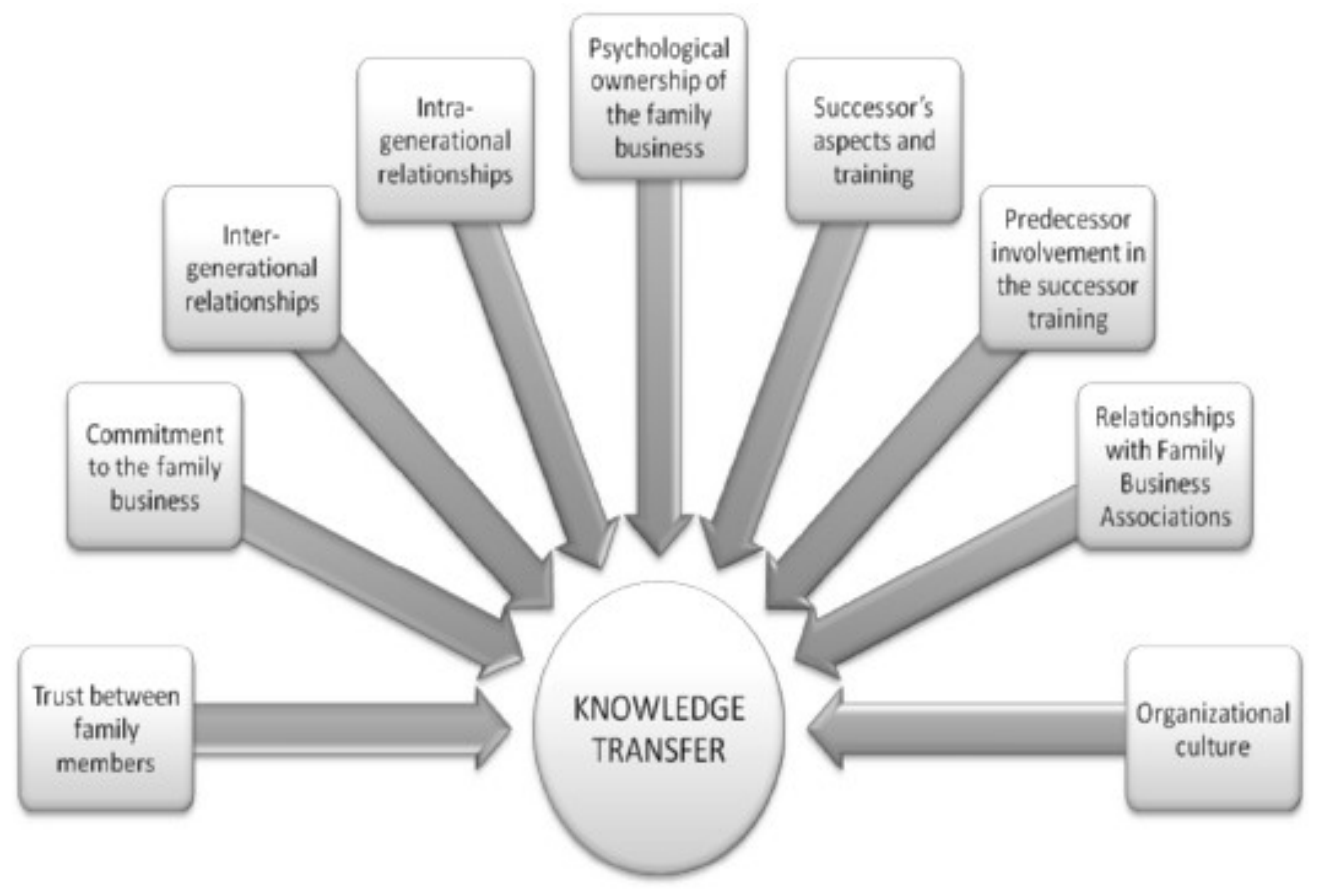

Figure 1. Factors influencing the knowledge transfer in family firms

\section{Trust between family members}

In knowledge transfer process is very important the human factor as well as motivation, commitment, working family relationships within the family business, trust between its members, etc. (Zapata et al., 2009). Knowledge acquisition only is successful when people are willing to cooperate. This willingness to cooperate, in turn, depends largely on the level of trust in an organization (Barachini, 2009).

The family context, characterized by harmony, values and principles, is more likely to foster a quality relationship between family members. Family businesses are considered an ideal context for the development of misunderstandings and conflicts that affect business results either positively or negatively (Bracci, 2008). Thus, tasks or functional conflicts may be beneficial to the development of successors, especially over the creativity of themselves and the quality of decisions, because tasks conflict attributes to successors' cognitive diversity, 
which is related to innovation and skills to solve complex and unusual problems (Comeche Martínez, 2007).

In multigenerational businesses, where several generations work together, exchange ideas and promote mutual learning. In this way, to have family interactions face to face and more generations work well together, help family members to create, share and transfer their knowledge (Chirico, 2008). As regards relationships among families, the more families are united and less physical distance has, the easier knowledge transmission will be, since there will be more opportunities for informal contacts (Zapata et al., 2009). During the informal contacts is where more knowledge is acquired, because are transmitted unconsciously; this communication between family members allows the exchange of knowledge, especially tacit knowledge (Trevinyo-Rodríguez \& Tàpies, 2010).

\section{Commitment to the family business}

A very important aspect related to the development of leadership in a succession process is the level of successors' commitment and motivation, which reflects an emotional bond with the organization characterized by the desire to enter and remain in it: as well as predecessors' motivation and commitment (Bracci, 2008; Le Breton-Miller et al., 2004; Sallán, 2006). However, to Cabrera and Martín (2010), in some cases, the incorporation of the successor in the company is related to a sense of obligation and loyalty to the family. These two commitment dimensions, affective and normative respectively, can do that successors have completely different behaviors. So, when commitment is affective, successors will be more committed to the company and will be identify and involve more with business's goals. Nevertheless, when the commitment is normative, successors will not dedicate the maximum effort to the company or will not fully appreciate what they have of it, because they will be on the company by obligation and not by vocation.

Organizations that are successful in knowledge generation and transmission are those able to create high levels of motivation (Endres et al., 2007) and employee commitment to the organization (Camelo, García \& Sousa, 2010). In this sense, greater affective commitment to the family business means more creation, sharing and knowledge transfer.

\section{Intergenerational relationships}

Cabrera-Suarez et al. (2001) point that the quality of the inter-generational relationship is important because it can affect the ability of the predecessors to teach and train their offspring, so that it is possible the important knowledge transmission to the company (Bracci, 2008). Therefore (Cabrera \& Martín, 2010), if the relationship between old generation and new generation is characterized by an open, honest and mature communication, it will be possible 
that both can express their real vision and their expectations and desires in relation with the company, thus facilitating the knowledge transfer. Hence, a constant and effective interpersonal communication is required in order to maximize the levels of knowledge; this interpersonal communication produces the members' understanding and comprehension (Zapata et al., 2009).

The relationship between successors and predecessors is the foundation of a successful process (Le Breton-Miller et al., 2004). Tacit knowledge can be transferred and assimilated through the establishment of a shared understanding between two or more people, including common mechanisms and cognitive structures, metaphors and analogies, as well as anecdotes (Grant, 1996). This helps in the creation of a progressive transfer of tacit knowledge, both organizational and individual level.

\section{Intragenerational relationships}

One of the most important obstacles to the growth of family businesses is the aspect related to conflicts between successors (Ward, 1997). For that the relationships between same generation members function properly, its members must constantly invest in their relationships. That is, they should be able to talk to solve problems, to reach to acceptable solutions for all, to follow a code of mutual understanding, and so on.

When the same generation members work together, often they play different roles. Simultaneously they can be families, owners, employees, bosses, subordinates, managers, etc. (Davis \& Tagiuri, 1993), which creates confusion among its members for failing to differentiate the business sphere from the family sphere (Kellermanns \& Eddleston, 2004). This diversity of roles among members of the same generation does that sometimes tend to appear jealous by the desire to have the position of another person, creating occasionally a barrier to the communication, thereby causing a lower knowledge transfer (Stanley et al., 1995).

In this way, it should be tried that intra-generational relationships are the least conflict possible, to avoid interfering in the optimal development of the company. To do this, it is necessary a conscious effort to meet and understand the each other's needs, a clear roles definition of each generation member, and smooth and sincere communication allowing at the same time to manage relationships with other family members (Corona, 2005) It is also necessary to develop mechanisms for sharing information and having an effective communication between members (Handler, 1991). Therefore, good relationships between the same family members are going to allow a greater transfer of knowledge. 


\section{Psychological ownership of the family business}

Following Chirico (2008), psychological ownership refers to the emotional feeling possessed by family members over the family business, with a strong sense of identity, residence, responsibility and control over it. That is, to invest a lot of energy, time, money and emotions in the family business is part of the identity and culture of the family members that increase their feelings of ownership over the organization. Family ownership reinforces the family members' psychological identification with and the involvement in the family business, stimulating learning and knowledge transfer (Zahra, 2012).

The business becomes an extension of themselves with all family members acting to maintain the continuity of the organization through the accumulation of knowledge. The current generations' hope is that following generations feel the same emotion for the company, enabling an easier knowledge transfer process (Chirico, 2008). A fundamental requirement of this psychological implication is the motivation. The lack of motivation may cause delays, inaction or rejection in adoption and use of new knowledge (Bracci, 2008).

\section{Successor's aspects and training}

Preparing successors for leadership involves knowing the key aspects of the company, the sector where it operates, developing management skills and gaining knowledge of themselves. So it is necessary that the training process is both before joining the company as once incorporated in it (Cabrera \& Martín, 2010). For this, successor must have a significant absorption capacity to understand, embrace and exploit the new knowledge gained through their predecessors (Argote \& Ingram, 2000; Zapata et al., 2009).

According to Chirico (2008), is also very important for successors to attend academic courses and practical training courses both inside and outside the family business, as this allows them to acquire explicit and tacit knowledge and develop skills that, once incorporated into the family business, must be shared and transferred to the other company members. Similarly, (Cabrera-Suarez et al., 2001) working outside the family business gives a more independent perspective on how to lead and how to introduce changes and innovations in the business. Once acquired, the knowledge needs to be shared and transferred over time. Experience outside the family firm helps successors to develop a knowledge base and a sense of identity.

Another important aspect is the successor's ability to maintain relationships with stakeholders such as employees, customers, suppliers, etc. (Bracci, 2008) and gaining respect and legitimacy (Le Breton-Miller et al., 2004). 


\section{Predecessor involvement in the successor training}

The predecessor or founder is the main source of knowledge in the family business. He should be motivated and aware of the necessary steps through business succession and the gradual loss of power and activity in the day to day and strategic decisions. So he should work and put effort to support the transfer of knowledge (Le Breton-Miller et al., 2004). However, especially in the first generation family businesses, there is lack of adequate systems for training and development of policies skills, because of the founders do not have time to train future leaders or not want to delegate responsibilities; this implies that successor do not have the opportunity to make their own decisions and develop their ideas and initiatives (Cabrera \& Martín, 2010). The first step to achieving this is the consciousness of this need and the predecessor's motivation and active involvement in the successors' training and development, resulting in effective knowledge transfer, what will facilitate their access to the company. Thus, the predecessor should involve and delegate functions and power to successors, and in turn maintain a supervisory and observation role (Bracci, 2008).

To Cabrera and Martín (2010), a high quality relationship between predecessors-successors (based on respect, mutual trust and communication) has a positive influence on predecessors' involvement in successors' training, which is the basis for the knowledge transmission between generations. However, in some cases, this knowledge cannot be the most appropriate to ensure proper development of the company, either because the business environment requires new knowledge and skills or because the existing knowledge does not generate competitive advantages for the company. In these cases, knowledge transfer will affect negatively to business performance.

\section{Relationships with Family Business Associations}

In some countries there are Regional Associations formed by family businesses in various sectors of activity. These family business associations have four main objectives:

- improving the legal framework of family businesses,

- carrying out training and advice activities in order to contribute to the continuity and strengthening of the family business,

- increasing awareness of family businesses among the public

- being a meeting point for business people.

In this case, families acquire from theses associations knowledge about family firms in general and their firms in particular in order to promote its continuity. They have a Family Forum for the development of educational activities for next generation members. Therefore, these 
associations can also contribute to a greater transmission of knowledge within the family firm (De La Maza-y-Aramburu, Vendrell-Herrero \& Wilson, 2012).

\section{Organizational culture}

The organizational culture is considered to be a critical factor in building and reinforcing knowledge management in organizations as it impacts how members learn, acquire and share knowledge (Rai, 2011). The type of dominant culture in the company will facilitate or hinder the knowledge sharing (Suppiah \& Sandhu, 2011).

The way a person behave in a job not only depends on their personal characteristics but also the way he perceives his workplace and his organization components, so organizational culture is a configuration of the company characteristics (Rodríguez-Zapatero, 2011). When there is a setting that encourages creativity, flexibility and compatibility of values such as sacrifice and work, with new ones such as new technologies, leisure, family and happiness through good humor, family relationships are favored and therefore the transfer of knowledge (Lozano, 2003). To make the workplace highly satisfactory and suggestive, it should be fostered an extensive creativity, opportunities for important making-decisions, collaboration with important colleagues, participation in other activities not related to the company, etc. (Ward \& Aronoff, 2001).

Therefore, Chirico and Nordqvist (2010) argue that knowledge and organizational culture characteristics are crucial for family firms' transgenerational value creation. They explain that a closed culture fosters family inertia so as to negatively impacts on resource-recombination processes; and an open culture it is contrarily.

\section{Discussion, conclusions and future research}

Family businesses have a relatively short life expectancy. It is estimated that only $30 \%$ of family businesses survive the transition from first to second generation, and of these, only $15 \%$ are still active in the third generation (Gallo, 1998). The failure of family firms from the second generation may be due to the lack of ability or willingness of the family to create, share and transfer knowledge from one generation to another and among the same generation, that is, intra and inter-generation. Thus, knowledge can contribute to the survival of family firm.

We have defined knowledge transfer as the communication process of knowledge from one generation to another or between the same generation. This knowledge concept includes information, experiences, beliefs, values, insights, know-how and skills. Once defined, we have analyzed the factors, aspects or characteristics that make up the knowledge transfer, in terms of relationships between members, commitment, successors' training and experience, 
predecessor involvement, relationships with associations, and so on.

Tacit knowledge can be lost if it is not shared and passed down from one generation to another in the form of learning. This knowledge can be more easily shared and transferred within family businesses because they have special characteristics that differentiate them from nonfamily firms. In family firms, successors need to acquire knowledge from the previous generation, but also need to add the new knowledge they have acquired through their education and personal experience and share it among their generation and the rest of generations.

Knowledge is transferred best when family members value the following factors: trust between family members, commitment to the family business, intergenerational and intragenerational relationships, psychological ownership of the family business, successor's aspects and training, predecessor involvement in the successor training, organizational culture and relationships with Family Business Associations.

It is necessary to put into action the knowledge accumulated in the organization to generate new knowledge that allows to improve, innovate and be more competitive. A growing body of research suggests that family firms have to adapt to changing markets to survive, obtain profit, grow and create wealth. In this sense, to have a greater entrepreneurship is a good way to family businesses to thrive (Aldrich \& Cliff, 2003). Thereby, a future research could be based on analyzing how family businesses can promote the knowledge transfer behaviour among its members in order to improve their entrepreneurial orientation. Thus, people's willingness to share their knowledge plays an important role in the entrepreneurial capacity.

In this regard, this work will continue using these factors for measuring Knowledge Transfer in order to empirically testing a structural model that analyzes the causal relationship of KT, EO and performance. The results of this model will show that if KT influences family firm competitive success, it will be an interesting strategy to be developed by these companies.

Finally, another additional research line related to the conversion of Knowledge (tacit and explicit) will be developed following the classification proposed by Bañegil, Barroso and Sanguino (2013), in which they propose an adaptation of the SECI cycle to family businesses area, that we can see in Table 1. 


\begin{tabular}{|c|c|c|}
\cline { 2 - 3 } \multicolumn{1}{c|}{} & TACIT KNOWLEDGE & EXPLICIT KNOWLEDGE \\
\hline \multirow{2}{*}{ TACIT KNOWLEDGE } & Socialization & EXternalization \\
\cline { 2 - 3 } & SUCCESSION & PROTOCOL \\
\hline $\begin{array}{c}\text { EXPLICIT } \\
\text { KNOWLEDGE }\end{array}$ & Internalization & Combination \\
\cline { 2 - 3 } & $\begin{array}{c}\text { HANAMAN RESOURCE } \\
\text { MANAMENT (TRAINING) }\end{array}$ & GOVERNANCE BODIES \\
\hline
\end{tabular}

Table 1. The SECI Cycle in family businesses (Bañegil, Barroso \& Sanguino, 2013)

That is, it will be analyzed variables related to the conversion of tacit knowledge into explicit (and vice versa, in all its different combinations) focusing especially on the family business key issues developed in Table 1 (succession, protocol, human resource management and governance bodies). For example, it would be interesting to analyze in depth the empirical studies that show the key factors in the succession, and try to provide solutions based on intra and inter generational KT.

\section{References}

ALBIZU, E.; OLAZARAN, M.; LAVÍA, C.; OTERO, B. (2011). Relationship between vocational training centres and industrial SMEs in the Basque Country: A regional innovation system approach. Intangible Capital, 7(2): 329-355. http://dx.doi.org/10.3926/ic.2011.v7n2.p329-355

ALDRICH, H.; CLIFF, J. (2003). The pervasive effects of family on entrepreneurship: toward a family embeddedness perspective. Journal of Business Venturing, 18: 573-596. http://dx.doi.org/10.1016/S0883-9026(03)00011-9

ANDERSON, R.C.; REEB, D.M. (2003). Founding-family ownership and firm performance: evidence from the S\&P 500. The Journal of Finance, 58(3): 1301-1328. http://dx.doi.org/10.1111/1540-6261.00567

AÑEZ, C.; NAVA, Y (2009). Gestión del conocimiento del capital humano en las pequeñas empresas. Omnia, 15(1): 162-177.

ARGOTE, L.; INGRAM, P. (2000). Knowledge transfer: a basis for competitive advantage in firms. Organizational Behavior and Human Decision Processes, 82(1): 150-169. http://dx.doi.org/10.1006/obhd.2000.2893

ARGOTE, L.; INGRAM, P.; LEVINE, J.M.; MORELAND, R.L. (2000). Knowledge transfer in organizations: learning from the experience of others. Organizational Behavior and Human Decision Processes, 82(1): 1-8. http://dx.doi.org/10.1006/obhd.2000.2883 
ASTRACHAN, J.H.; KLEIN, S.B.; SMYRNIOS, K.X. (2002). The F-PEC scale of family influence: A proposal for solving the family business definition problem. Family Business Review, 8(2): 45-58. http://dx.doi.org/10.1111/j.1741-6248.2002.00045.x

BAÑEGIL, T.M.; SANGUINO, R. (2006). Intellectual capital within Iberian municipalities (network). Journal of Knowledge Management, 10(5): 55-64. http://dx.doi.org/10.1108/13673270610691170

BAÑEGIL, T.M.; SANGUINO, R. (2007). Intangible Measurement Guidelines: a Comparative Study in Europe. Journal of Intellectual Capital, 8(2): 192-204.

http://dx.doi.org/10.1108/14691930710742790

BAÑEGIL, T.M.; BARROSO, A.; SANGUINO, R. (2013). La gestión del conocimiento en las empresas familiares. Nuevas investigaciones sobre la gestión de la Empresa Familiar en España (pages 69-79). Barcelona: OmniaScience. http://dx.doi.org/10.3926/oms.03

BARACHINI, F. (2009). Cultural and social issues for knowledge sharing. Journal of Knowledge Management, 13(1): 98-110. http://dx.doi.org/10.1108/13673270910931198

BARNEY, J. B. (1991). Firm resources and sustained competitive advantage. Journal of Management, 17(1): 99-120. http://dx.doi.org/10.1177/014920639101700108

BARNEY, J.B. (2001). Resource-based theories of competitive advantage: A ten-year retrospective on the resource-based view. Journal of Management, 27: 643-650. http://dx.doi.org/10.1177/014920630102700602

BARROSO, A.; SANGUINO, R.; BAÑEGIL, T.M. (2012). Diferentes criterios del concepto de empresa familiar. Una aportación desde Extremadura, España. Ide@s Concyteg, 83(7): 611622.

BASCO, R. (2010). Tipo de orientación familiar y prácticas de dirección y gobierno. Un estudio aplicado a las empresas familiares españolas. Revista Europea de Dirección y Economía de la Empresa, 19(2): 129-144.

BRACCI, E. (2008). A knowledge framework for understanding small family business succession process. IUP Journal of Knowledge Management, Forthcoming. Available at SSRN: http://ssrn.com/abstract=1184620.

BRACHOS, D.; KOSTOPOULOS, K.; SODERQUIST, K.E.; PRASTACOS, G. (2007). Knowledge effectiveness, social context and innovation. Journal of Knowledge Management, 11(5): 31-44. http://dx.doi.org/10.1108/13673270710819780

BUENO, E. (1999a). Dirección del conocimiento y aprendizaje: creación, distribución y medición de intangibles. Instituto Universitario Euroforum Escorial, Madrid. 
BUENO, E. (1999b). El consejo de administración y la gestión del conocimiento. Instituto Universitario Euroforum Escorial. Madrid.

CABRERA, K; MARTÍN, J. (2010). La influencia de las relaciones intergeneracionales en la formación y el compromiso del sucesor: efectos sobre el proceso de sucesión de la empresa familiar. Revista Europea de Dirección y Economía de la Empresa, 19(2): 111-128.

CABRERA-SUÁREZ, K.; SAÁ-PÉREZ, P.; GARCÍA-ALMEIDA, D. (2001). The succession process from a resource-and knowledge-based view of the family firm. Family Business Review, 14(1): 37-48. http://dx.doi.org/10.1111/j.1741-6248.2001.00037.x

CAMELO, C.; GARCÍA, J.; SOUSA, E. (2010). Facilitadores de los procesos de compartir conocimiento y su influencia sobre la innovación. Cuadernos de Economía y Dirección de Empresa, 42: 113-150. http://dx.doi.org/10.1016/S1138-5758(10)70005-0

CHIRICO, F. (2008). Knowledge accumulation in family firms: evidence from four cases studies. International Small Business Journal, 26: 433-462. http://dx.doi.org/10.1177/0266242608091173

CHIRICO, F.; NORDQVIST, M. (2010). Dynamic capabilities and trans-generational value creation in family firms: the role of organizational culture. International Small Business Journal, 28(5): 487-504. http://dx.doi.org/10.1177/0266242610370402

CHIRICO, F.; SALVATO, C. (2008). Knowledge integration and dynamic organizational adaptation in family firms. Family Business Review, 21(2): 169-181. http://dx.doi.org/10.1111/j.1741-6248.2008.00117.x

CHIRICO, F.; SIRMON, D.G.; SCIASCIA, S.; MAZZOLA, P. (2011). Resource orchestration in family firms: investigating how entrepreneurial orientation, general involvement and participative strategy affect performance. Strategic Entrepreneurship Journal, 5(4): 307326. http://dx.doi.org/10.1002/sej.121

CHRISMAN, J.J.; CHUA, J.H.; SHARMA, P. (2003). Current trends and future directions in family business managements studies: toward a theory of the family firm. Coleman White Paper Series.

CHRISMAN, J.J.; KELLERMANNS, F.W.; CHAN, K.C.; LIANO, K. (2010). Intellectual foundations of current research in family business: an identification and review of 25 influential articles. Family Business Review, 23(1): 9-26. http://dx.doi.org/10.1177/0894486509357920

CHUA, J.H.; CHRISMAN, J.J.; SHARMA, P. (1999). Defining the family business by behavior. Entrepreneurship Theory and Practice, 23(1): 19-39. 
COMECHE MARTÍNEZ, J.M. (2007). Influencia de los factores conductuales en la capacidad de acumulación, generación y transmisión de conocimientos en los entrepreneurial team de la organización en Decisiones basadas en el conocimiento y en el papel social de la empresa. XX Congreso Anual de AEDEM, 1, 73.

CONNER, K.R.; PRAHALAD, C.K. (1996). A Resource-Based Theory of the Firm: Knowledge versus Opportunism. Organization Science, 7(5): 477-501. http://dx.doi.org/10.1287/orsc.7.5.477

CORONA, J. (editor) (2005). Manual de la Empresa Familiar. Barcelona: Ediciones Deusto.

DAVIS, J.; TAGIURI, R (1993). Fases vitales y relaciones laborales padre-hijo. La EF 4; IESE.

DAVIS, P. (1983). Realizing the potential of the family business. Organizational Dynamics, verano: 47-56.

DE LA MAZA-Y-ARAMBURU, X.; VENDRELL-HERRERO, F.; WILSON, J.R. (2012). Where is the value of cluster associations for SMEs?. Intangible Capital, 8(2): 472-496. http://dx.doi.org/10.3926/ic.346

DONCKELS, R.; FRÖHLICH, E. (1991). Are family business really different? European experiences from STRATOS. Family Business Review, 4(2): 149-10. http://dx.doi.org/10.1111/j.1741-6248.1991.00149.x

ENDRES, M.L.; ENDRES, S.P.; CHOWDHURY, S.K.; ALAM, I. (2007). Tacit knowledge shraring, self-efficacy theory, and application to the Open Source community. Journal of Knowledge Management, 11(3): 92-103. http://dx.doi.org/10.1108/13673270710752135

FAHED-SREIH， J.; DJOUNDOURIAN, S. (2006). Determinants of Longevity and Success in Lebanese Family Business: an exploratory study. Family Business Review, 19(3): 225-234. http://dx.doi.org/10.1111/j.1741-6248.2006.00071.x

FUENTES, G.; FERNÁNDEZ-ORTIZ, R.; CANO-RUBIO, M. (2011). Intangibles en la internacionalización de las bodegas españolas: Percepción directiva y comparada entre empresas familiares y no familiares. Intangible Capital, 7(2): 428-473.

GALLO, M.A. (1998). La sucesión en la empresa familiar. Colección Estudios e Informes de la Caixa, 12. Barcelona.

GIOVANNONI, E.; MARAGHINI, M.P.; RICCABONI, A. (2011). Transmitting Knowledge Across Generations: The Role of Management Accounting Practices. Family Business Review, 24(2): 126-150. http://dx.doi.org/10.1177/0894486511406722

GONZÁLEZ-LOUREIRO, M.; FIGUEROA, P. (2012). Intellectual capital and system of innovation: What really matters at innovative SMEs. Intangible Capital, 8(2): 239-274. http://dx.doi.org/10.3926/ic.273 
GRANT, R. (1991). A resource-based theory of competitive advantage: implications for strategy formulation. California Management Journal, 33(3): 114-135. http://dx.doi.org/10.2307/41166664

GRANT, R. (1996). Toward a Knowledge-Based Theory of the Firm. Special Issue: Knowledge and the Firm (Winter, 1996). Strategic Management Journal, 17: 109-122

GU, Q.; GU, Y. (2011). A factorial validation of knowledge sharing motivation contruct. Journal of Service and Management, 4: 59-65. http://dx.doi.org/10.4236/jssm.2011.41009

HABBERSHON, T.; WILLIAMS, M. (1999). A resource-based framework for assessing the strategic advantages of family firm. Family Business Review, 12(1): 1-25. http://dx.doi.org/10.1111/j.1741-6248.1999.00001.x

HANDLER, W.C. (1991). Key interpersonal relationships of next-generation family members in family firms. Journal of Small Business Management, 23(3): 21-32.

HENDRIKS, P. (1999). Why share knowledge? The influence of ICT on the motivation for knowledge sharing. Knowledge and Process Management, 6(2): 91-100. http://dx.doi.org/10.1002/(SICI)1099-1441(199906)6:2<91: :AID-KPM54>3.0.CO;2-M

HOFFMAN, J.; HOELSCHER, M.; SORENSON, R. (2006). Achieving sustained competitive advantage: a family capital theory. Family Business Review, 19(2): 135-145. http://dx.doi.org/10.1111/j.1741-6248.2006.00065.x

HUTCHINSON, V.; QUINTAS, P. (2008). Do SMEs do knowledge management? Or simply manage what they know?. International Small Business Journal, 26(2): 131-154. http://dx.doi.org/10.1177/0266242607086571

IRELAND, R.D.; HITT, M.A. (1999). Achieving and maintaining strategic competitiveness in the 21st century: The role of strategic leadership. Academy of Management Executive, 13(1): 43-57.

KELLERMANNS, F.W; EDDLESTON, K.A (2004). Feuding Families: When Conflict Does a Family Firm Good. Entrepreneurship, Theory and Practice, 28(3): 209-228. http://dx.doi.org/10.1111/j.1540-6520.2004.00040.x

KUMAR, J.A.; GANESH, L.S. (2009). Research on knowledge transfer in organizations: a morphology. Journal of Knowledge Management, 13(4): 161-174. http://dx.doi.org/10.1108/13673270910971905

LANSBERG, I.S.; PERROW, E.L.; ROGOLSKY, S. (1988). Family business as an emerging field. Family Business Review, 1(1): 1-8. http://dx.doi.org/10.1111/j.1741-6248.1988.00001.x

LANSBERG, I.; ASTRACHAN, J.H. (1994). Influence of Family Relationships on Succession Planning and Training: The Importance of Mediating Factors. Family Business Review, 7(1): 39-59. http://dx.doi.org/10.1111/j.1741-6248.1994.00039.x 
LE BRETON-MILLER, I.; MILLER, D.; STEIERS, L.P. (2004). Toward an integrative model of effective FOB succession. Entrepreneurship Theory and Practice, 28(4): 305-328. http://dx.doi.org/10.1111/j.1540-6520.2004.00047.x

LIU, J (2010). Culture and knowledge transfer: theoretical considerations. Journal of Service Science and Management, 3: 159-164. http://dx.doi.org/10.4236/jssm.2010.31020

LOZANO, M. (2003). Las relaciones intrafamiliares en la empresa familiar. Revista Pensamiento y Gestión, 15: 83-110.

LU, L.; LEUNG, K.; KOCH, P.T. (2006). Managerial knowledge sharing: The role of individual, interpersonal, and organizational factors. Management and Organization Review, 2(1): 15-41. http://dx.doi.org/10.1111/j.1740-8784.2006.00029.x

MARCU, R.; WATTERS, B. (2003). Portales de conocimiento: colaboración y productividad de nueva generación. Madrid: Ed McGraw Hill.

MAROUF, L N. (2007). Social networks and knowledge sharing in organizations: a case study. Journal of Knowledge Management, 110-125. http://dx.doi.org/10.1108/13673270710832208

MAZZOLA, P.; MARCHISIO, G.; ASTRACHAN, J. (2008). Strategic planning in family business: A powerful developmental tool for the next generation. Family Business Review, 21:239-258.

MILLER, D.; SHAMSIE, J. (1996). The resource-based view of the firm in two environments: the Hollywood films studios from 1936 to 1965. Academy of Management Journal, 3(3): 519-543. http://dx.doi.org/10.2307/256654

MOORES, K. (2009). Paradigms and theory building in the domain of business families. Family Business Review, 22(2): 167-180. http://dx.doi.org/10.1177/0894486509333372

NAVARRO DE GRANADILLO, K. (2008). Estado actual de la investigación sobre la gestión del conocimiento en empresas familiares. Revista de Ciencias Sociales, vol. 14(1): 30-45.

NEUBAUER, F.; LANK, A.G. (2003). La empresa familiar. Cómo dirigirla para que perdure. Bilbao: Ediciones Deusto.

PATEL, P.O.; FIET, J.O. (2011). Knowledge combination and the potential advantages of family firms in searching for opportunities. Entrepreneurship Theory and Practice. Special Issue: Theory of the Family Enterprise, 35(6): 1179-1197.

PISTRUI, D.; HUANG, W.; OKSOY, D.; JING, Z.; WELSCH, H. (2001). Entrepreneurship in China: characteristics, attributes and family forces shaping the emerging private sector. Family Business Review, 14(2): 141-152. http://dx.doi.org/10.1111/j.1741-6248.2001.00141.x

PRIEM, R.L.; BUTLER, J.E. (2001). Is the resource-based "view" a useful perspective for strategic management research?. The Academy of Management Review, 26(1): 22-40. 
RAI, R.K. (2011). Knowledge management and organizational culture: a theoretical integrative framework. Journal of Knowledge Management, 15(5): 779-801. http://dx.doi.org/10.1108/13673271111174320

RAY, G.; BARNEY, J.; MUHANNA, W. (2004). Capabilities, business processes, and competitive advantage: choosing the dependent variable in empirical tests of the resource-based view. Strategic Management Journal, 25: 23-37. http://dx.doi.org/10.1002/smj.366

RODRÍGUEZ ZAPATERO, M. (2011). Mapa de la cultura organizativa de la empresa familiar: un estudio de casos en la provincia de Córdoba. Revista de Empresa Familiar, 1(2): 59-70.

RUIZ, M.; SESSAREGO, A.; GUZMAN-SANZA, R. (2010). A research about of family firm definition. Available at SSRN: http://ssrn.com/abstract=1551410 (Last access date; February 11th, 2010).

SALLÁN, J.M. (2006). Caracterización de los grupos informales de transmisión de conocimiento mediante el análisis de redes sociales. Intangible Capita, . 2: 21-36.

SALVATO, C.; MELIN, L. (2008). Creating value across generations in family controlled businesses: the role of family social capital. Family Business Review, 23(3): 259-276.

SIRMON, D.G.; HITT, M.A.; IRELAND, R.D. (2007). Managing firm resources in dynamic environments to create value: looking inside the black box. Academy of Management Review, 32(1): 273-292. http://dx.doi.org/10.5465/AMR.2007.23466005

SIRMON, D.G.; HITT, M.A. (2003). Managing resources: linking unique resources, management and wealth creation in family firms. Entrepreneurship Theory and Practice, 27: 339-358. http://dx.doi.org/10.1111/1540-8520.t01-1-00013

STANLEY, C.; STEPHENSON, B.; MONTEITH, D. (1995). The management of family firm: an empirical investigation. International Small Business Journal, 13(4): 11-34. http://dx.doi.org/10.1177/0266242695134001

SUPPIAH, V.; SANDHU, M.S. (2011). Organisational culture's influence on tacit knowledgesharing behavior. Journal of Knowledge Management, 15(3): 462-477. http://dx.doi.org/10.1108/13673271111137439

TAGIURI, R.; DAVIS, J. (1996). Bivalent attributes of the family firm. Family Business Review, 9(3): 199-208. http://dx.doi.org/10.1108/13673271111137439

TREVINYO-RODRÍGUEZ, R.N.; TÀPIES, J. (2010). Effective knowledge transfer in family business. Working Paper-865. IESE. Business School of Navarra.

WARD, J.L. (1997). Growing the family business: special challenges and best practices. Family Business Review, 10(4): 323-337. http://dx.doi.org/10.1111/j.1741-6248.1997.00323.x 
WARD, J.L.; ARONOFF, C.E. (2001). Satisfacción laboral en la empresa familiar. Asesoría y consultoría de la empresa familiar, 5. Barcelona.

WATSON, S.; HEWETT, K. (2006). A multi-theoretical model of knowledge transfer in organizations: determinants of knowledge contribution and knowledge reuse. Journal of Management Studies, 43(2): 141-173. http://dx.doi.org/10.1111/j.1467-6486.2006.00586.x

WONG, K.Y.; ASPINWALL, E. (2004). Characterizing knowledge management in the small business environment. Journal of Knowledge Management, 8(3): 44-61. http://dx.doi.org/10.1108/13673270410541033

ZACK, M.; MCKEEN, J.; SINGH, S. (2009). Knowledge management and organizational performance: an exploratory analysis. Journal of Knowledge Management, 13(6): 392-409. http://dx.doi.org/10.1108/13673270910997088

ZAHRA, S.A. (2012). Organizational learning and entrepreneurship in family firms: exploring the moderating effect of ownership and cohesion. Small business economics, 38(1): 51-65. http://dx.doi.org/10.1007/s11187-010-9266-7

ZAHRA, S.; NEUBAUM, D.; LARRAÑETA, B. (2007). Knowledge sharing and technological capabilities: the moderation role of family involvement. Journal of Business Research, 60: 1070-1079. http://dx.doi.org/10.1016/j.jbusres.2006.12.014

ZAPATA, L.; RIALP, J.; RIALP, A. (2009). Generation and transfer of knowledge in IT-related SMEs. Journal of Knowledge Management, 13(5): 243-256. http://dx.doi.org/10.1108/13673270910988088

ZÁRRAGA OBERTY, C.; BONACHE PÉREZ, J. (2005). Equipos de trabajo para la gestión del conocimiento: la importancia de un clima adecuado. Cuadernos de Economía y Dirección de la Empresa, 22: 27-48.

ZHANG, L.; ZHENG, X.; LI, J.; NIE, G.; HUO, G; SHI, Y. (2008). A Way to Improve Knowledge Sharing: from the Perspective of Knowledge Potential. Journal of Service Science and Management, 1: 226-232. http://dx.doi.org/10.4236/jssm.2008.13024

Intangible Capital, 2013 (www.intangiblecapital.org)

\section{(C)}

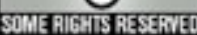

Article's contents are provided on a Attribution-Non Commercial 3.0 Creative commons license. Readers are allowed to copy, distribute and communicate article's contents, provided the author's and Intangible Capital's names are included. It must not be used for commercial purposes. To see the complete license contents, please visit http://creativecommons.org/licenses/by-nc/3.0/. 